\title{
Research into technology of fastening the mine workings in the conditions of unstable masses
}

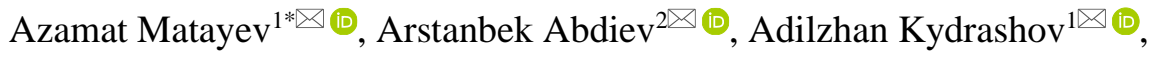 \\ Aibek Musin $^{1 \otimes(\infty)}$, Natalia Khvatina ${ }^{3 \otimes(\bullet)}$, Dinara Kaumetova ${ }^{1 \otimes(1)}$ \\ ${ }^{1}$ Karaganda Technical University, Karaganda, 100017, Kazakhstan \\ ${ }^{2}$ Kyrgyz State Mining University, Bishkek, 720001, Kyrgyzstan \\ ${ }^{3}$ Kokshetau University named after Shokan Ualikhanov, Kokshetau, 20000, Kazakhstan \\ *Corresponding author: e-mail mataev.azamat@mail.ru, tel.+77023920146
}

\begin{abstract}
Purpose. Determination of the rock stability along the strike of the mass, where the drift mining of the horizon $-480 \mathrm{~m}$ is conducted, considering the possibility of using the improved types of supports in the conditions of the $10^{\text {th }}$ Anniversary of Kazakhstan's Independence mine at the Khromtau field with the substantiation of using the effective type of fastening that increases technical and technological, operational and economic indicators of the mine.

Methods. Numerical modelling of the stress-strain state of the rock mass applied at the mine have been performed using the RS2 software in a two-dimensional formulation. The rock mass state, as well as the physical-mechanical properties of mine rocks are determined according to building codes and regulations (SNiP II-94-80), depending on the category of the rock stability.

Findings. It has been revealed that the combined supports from rock bolts and shotcrete are the most rational type of fastening in the studied mine. The efficiency and prospects of using the combined supports have been determined, which ensure a decrease in their material consumption and cost while increasing the reliability of mine workings and the labor productivity of miners. The use of combined support allows to increase the economy of materials for support by 1.7 times, as well as to increase the drifting rate by 1.6 times in comparison with the metal support.

Originality. The paper proposes a new approach to substantiation of an effective fastening method by comparing the costs when driving horizontal underground mine workings in the mining-and-geological conditions of the $10^{\text {th }}$ Anniversary of Kazakhstan's Independence mine.

Practical implications. The research results can be used when planning mining operations, in particular, stable fastening methods at the $10^{\text {th }}$ Anniversary of Kazakhstan's Independence mine of the Khromtay deposit, as well as other mining enterprises with similar mining-and-geological conditions.
\end{abstract}

Keywords: mine, ore, rock bolt, rock, metal support, drift, deposit

\section{Introduction}

An increase in the competitiveness of coal mining is directly related to a decrease in the final product cost in terms of the main items of expenditure, among which the costs for maintaining the mine workings are of great importance [1], [2].

The near-term and long-term prospects for the mining industry development in Kazakhstan are inextricably linked with the intensification of technological processes for the extraction of mineral raw materials, in which the maintanence of a wide-area network of preparatory workings (both main and zonal) in proper operational state is a very urgent and important scientific-technical task. The overwhelming majority of these mine workings are located in a very heterogeneous rock mass structure with rather active rock pressure manifestations, which leads to the consumption of significant resources for their maintenance and significantly affects the cost of mined ore.

The $10^{\text {th }}$ Anniversary of Kazakhstan's Independence mine is located in the north of Mugalzhar, on the eastern slope of the East Kempirsay ore district, in the south-eastern part of Khromtau City, Aktobe region, Republic of Kazakhstan. The Rudnichny District infrastructure is well developed. Next to the $10^{\text {th }}$ Anniversary of Kazakhstan's Independence mine, the mines of Donskoy Ore Mining and Processing Plant, Voskhod Mine, the $20^{\text {th }}$ anniversary of the Kazakh S.S.R. Mine and Poiskovoye open-pit mine are developing chromite deposits. An enrichment plant for 
processing of chromite ores produced at these deposits is located three kilometers north of the Molodezhnaya mine.

The main part of the field reserves will be mined by an undercut-caving system. Based on the fact that the ore bodies of the fields have a continuous slightly inclined or inclined angle of occurrence and in some places the ore bodies move abruptly upward within a level, then parts of one block reserves are located at different levels in relation to mine workings of the haulage horizon [3].

Such reserves within one block are prepared to mining by both high and low undercutting of sub-levels. Within the mining allotment area, two types of groundwater are developed: pore water - in Cretaceous and Paleogene deposits and fissure water - in the rocky Paleozoic mass. Groundwater in Cretaceous and Paleogene deposits has sporadic distribution. It does not have an independent significance in the formation of water inflows into underground mine workings.

Fissure water developed in the rocky ore-bearing mass is the main source of flooding of the mine workings and is subdivided into fissure-ground and fissure-vein. Its distribution is confined to the zones of open fracturing of the metamorphosed intrusive rocks of basic and ultrabasic composition, represented by gabbro-amphibolites and serpentinites through dunites and peridotites [4]-[6].

At present, work on fastening of mine workings, when mining the underground mine workings in open pits and mines, underground facilities erected for transport and communication, energy and other purposes, is of great importance. Accordingly, the purpose of this work is to study the rock stability along the strike of the mass, taking into account the possibility of using the improved types of supports.

\section{Methods}

\subsection{Geology of the studied area}

Serpentinites through dunites are widespread in the deposits of the $10^{\text {th }}$ Anniversary of Kazakhstan's Independence mine. Serpentinite is less widespread through pyroxene dunites. The mentioned rock types occur to a depth of 35-110 m from the Earth's surface. The maximum value of the desiccation degree is observed at a depth of $10-20 \mathrm{~m}$. The rocks are formed here by fine-grained rocks and changed to a clay mass. The plan of mining operations as of 10/07/20, sublevel $+60 \mathrm{~m}$, block 1 after mining operations is presented in Figure 1. Longitudinal sections 32 and 37 are also indicated here.

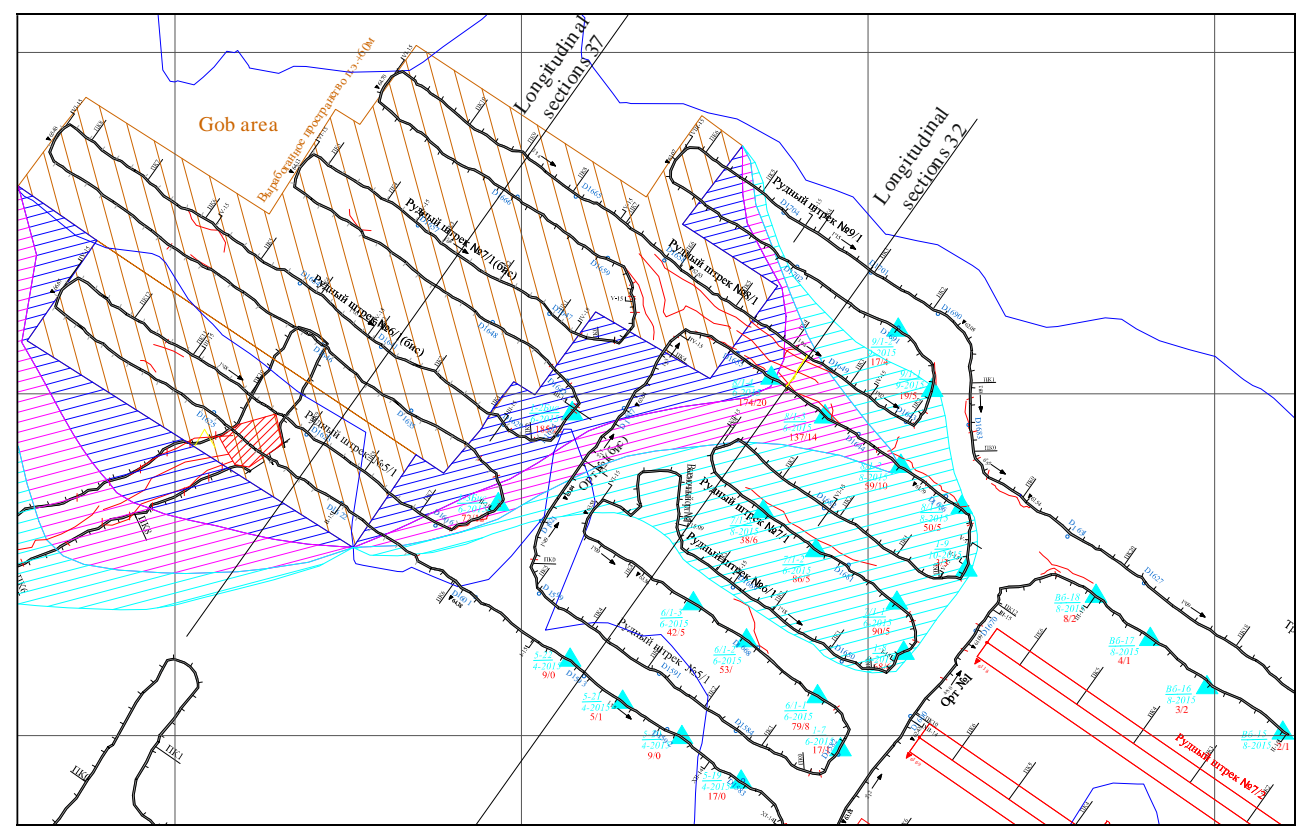

Figure 1. Plan of mining operations as of 10/07/20, sublevel +60 m, block 1 after mining operations

According to the laboratory surveys, three main engineering-geological rock complexes are identified [3], [7].

1) complex of ground carbonate, fine-grained serpentinites, with low rock strength $\left(R_{\text {compr }}=15.2 \mathrm{MPa}\right.$, $R_{p}=1.3 \mathrm{MPa}$, hardness coefficient according to the Protodyakonov scale is $f=2-3$, III drilling category), which is typical for the upper area of the deposit;

2) complex of serpentinized dunites:

- less crack-resistant dunite is durable $\left(R_{\text {compr }}=55.3 \mathrm{MPa}\right.$, $R_{p}=4.3 \mathrm{MPa}$, hardness coefficient according to the Protodyakonov scale is $f=9$, VII drilling category);

- root-mean-square dunite is represented by rocks of medium strength $\left(R_{\text {compr }}=27.1 \mathrm{MPa}, R_{p}=3.1 \mathrm{MPa}\right.$, hardness coefficient according to the Protodyakonov scale is $f=8$, VII drilling category);
- category of dunites refers to durable rocks $\left(R_{\text {compr }}=64.5 \mathrm{MPa}, R_{p}=4.5 \mathrm{MPa}\right.$, hardness coefficient according to the Protodyakonov scale is $f=9$, VII drilling category); - mid-season dunite is medium strength rock $\left(R_{\text {compr }}=35.1 \mathrm{MPa}, R_{p}=2.7 \mathrm{MPa}\right.$, hardness coefficient according to the Protodyakonov scale is $f=8$, VII drilling category);

- extra strong - low strength rocks $\left(R_{\text {compr }}=17.1 \mathrm{MPa}\right.$, $R_{p}=1.6 \mathrm{MPa}$, hardness coefficient according to the Protodyakonov scale is $f=6$, VI drilling category);

3) complex of serpentinized peridotites:

- rocks with low tensile strength $\left(R_{\text {compr }}=58.1 \mathrm{MPa}\right.$, $R_{p}=4.7 \mathrm{MPa}$, hardness coefficient according to the Protodyakonov scale is $f=8$, VII drilling category);

- rocks of medium strength $\left(R_{\text {compr }}=29.1 \mathrm{MPa}\right.$, $R_{p}=2.7 \mathrm{MPa}$, hardness coefficient according to the Protodyakonov scale is $f=8$, VII drilling category); 
- rocks of extra tensile strength $\left(R_{\text {compr }}=8.0 \mathrm{MPa}\right.$, $R_{p}=0.8 \mathrm{MPa}$, hardness coefficient according to the Protodyakonov scale is $f=2$, III drilling category).

With increasing depth, the rock strength increases. The compression strength of low-tonnage rocks and ores at great depths changes to a value of $60-120 \mathrm{MPa}$. According to geological data, the main ore deposit is mainly represented by continuous and densely disseminated ores, and the rocks in the field are represented by pyroxene-free dunites, pyroxene dunites and peridotites, serpentinized to varying degrees. Tables 1 and 2 present the generalized strength and physicalmechanical properties of the rock mass in the studied area.

Table 1. Strength properties of rocks and ores

\begin{tabular}{|c|c|c|c|c|}
\hline \multirow{3}{*}{ Name } & Physical properties & \multicolumn{3}{|c|}{ Strength properties } \\
\hline & \multirow[b]{2}{*}{ Rock density $(P), \mathrm{g} / \mathrm{cm}^{3}$} & \multicolumn{2}{|c|}{ Ultimate compression strength $\left(R_{\text {compr }}\right), \mathrm{MPa}$} & \multirow[b]{2}{*}{$\begin{array}{l}\text { Limit of strength } \\
\qquad\left(R_{p}\right), \mathrm{MPa}\end{array}$} \\
\hline & & $\begin{array}{c}\text { For monolithic-type } \\
\text { samples }\end{array}$ & $\begin{array}{l}\text { For samples with } \\
\text { primary fractures }\end{array}$ & \\
\hline Rock & 2.69 & $99.7-128.0$ & $41.6-61.0$ & $9.02-13.4$ \\
\hline Ore & 3.62 & $52.6-68.0$ & $30.2-54.0$ & $5.55-6.12$ \\
\hline
\end{tabular}

Table 2. Strength properties of rocks and ores

\begin{tabular}{|c|c|c|c|c|c|c|}
\hline \multirow{2}{*}{ Filler type } & \multicolumn{2}{|c|}{ Cohesion $(C), \mathrm{MPa}$} & \multicolumn{4}{|c|}{ Internal friction angle $(\varphi \varphi)$, degree } \\
\hline & minimal & maximal & medium & minimal & maximal & medium \\
\hline Siliceous-carbonate & 2.4 & 4.5 & 3.1 & 30 & 42 & 37 \\
\hline Talcum-micaceous & 0.45 & 3.1 & 1.9 & 17 & 44 & 33 \\
\hline Serpophytic & 1.8 & 9.6 & 6.0 & 20 & 43 & 35 \\
\hline Serpentine & 7.0 & 15.0 & 10.8 & 30 & 49 & 41 \\
\hline
\end{tabular}

\subsection{Experimental}

Numerical modelling of the rock mass stress-strain state and the calculation of the load-bearing capacity of the support types used at the $10^{\text {th }}$ Anniversary of Kazakhstan's Independence mine have been performed with the help of the RS2 software [8]. This program, based on the Finite Element Method in a two-dimensional formulation, makes it possible to take into account a significant number of factors influencing the mass state. The calculations take into account not only the physical-mechanical rock properties and the stresses acting in the mass, but also the structural characteristics of the mass, as well as the degree of technogenic impact. The Hoek-Brown model with its distinctive advantage of nonlinearity is used as a model for the mass behaviour [9], [10].

The data obtained in the RS2 software is similar to fullscale processes occurring in the conditions of mineral deposit development, and is widely used in many fields, since it allows to take into account such factors as the physicalmechanical properties of rocks and fractures, the presence of water, stress state, parameters of mine workings, types of support, effects of fixed loads, expected displacements, etc. The displacement of the mine working walls is fixed by tacheometric survey and superimposed in the Surpac program. The specified displacements are also analyzed in the Phase 2 program, and the physical-mechanical properties of rocks are processed in the RocLab program [11].

An important aspect of the research by the finite element method is the 'discreteness' of the computational experiment conditions with a certain set of specific values of the parameters included in the calculation [12], [13]. To summarize the recommendations designed for a certain range of mininggeological and mining-engineering conditions, it is necessary to identify a set of patterns of each parameter influence, which necessitates large-scale multifactorial computational experiments with subsequent processing the results obtained by the methods of correlation-dispersion analysis [14]-[18]. This requires a lot of time and thorough planning of the research algorithm, but, on the other hand, increases the degree of the geomechanical model objectivity and the reliability of subsequent geotechnical predictions for the stability of mine workings. The specified direction of solving the geomechan- ical problems seems to be the most promising, given the need to present and generalize the peculiarities of the mine working placement in the rock stratum, the characteristics of which differ significantly in other regions. The method of generalizing the results of multifactorial computational experiments is expedient to use in a complex with a constant comparative analysis of these existing experimental studies of the rock pressure manifestations [19]-[21].

Any prediction of rock pressure manifestations is based on a certain amount of mine observations, laboratory and analytical studies of the geomechanical process. Full-scale studies are performed in the studied mine working. The benchmark is set on both sides perpendicular to each other at a height from 1.0 to $2.0 \mathrm{~m}$, every $10 \mathrm{~m}$. The measurement is performed every week.

Rock bolts are considered the main load-bearing element (which combines the layers of masses) and the shotcrete support, along with the load-bearing capacity, binds the individual rock pieces, closes the fractures tightly and prevents caving [22]-[24]. In accordance with the step of lagging behind the face, specified in the passport of fastening, the support should be timely set (Fig. 2).

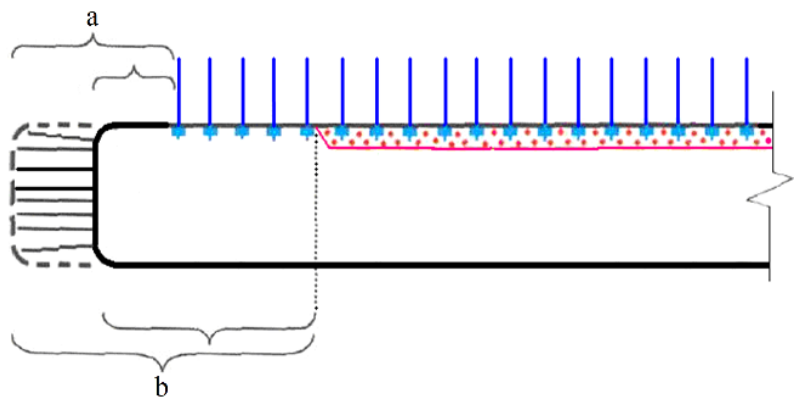

Figure 2. Scheme of lagging of the combined support behind the face before and after its advance: (a) rock-bolt suppor; (b) shotcrete support

In this paper, the arrangement of rock bolts on the roof is taken according to a square pattern of $0.7 \times 0.7 \mathrm{~m}$, used for fastening of the mine workings at the $10^{\text {th }}$ Anniversary of Kazakhstan's Independence mine of the Khromtau field, 
which is the object of research. Four rock bolts are set on the mine working roof. After the masses of driven mine workings become moderately stable, the setting of rock bolts on the sides is not provided.

It has been determined in the previous studies [7], [22], [23] that, depending on the geological and geomechanical conditions of load-bearing capacity of the main rock bolt types, as well as economic efficiency, it is reasonable to use the reinforced concrete rock bolts (Fig. 3).

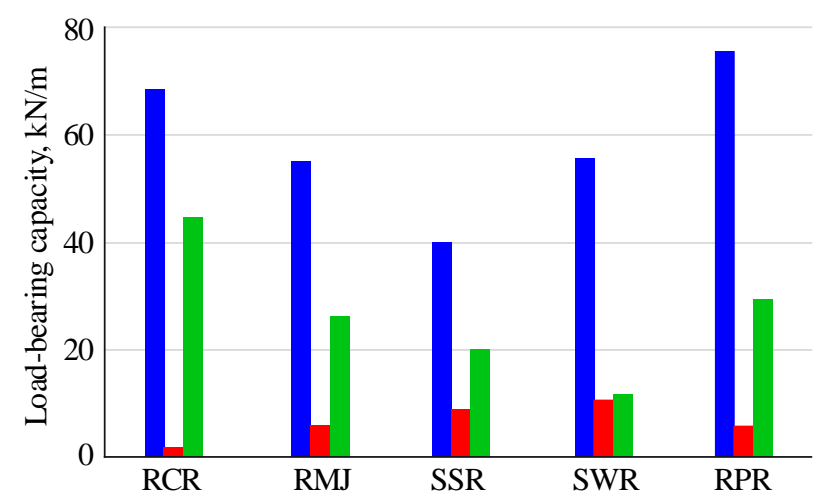

Figure 3. Results of selecting the type of rock bolts of various structure: $R C R$ - reinforced concrete rod; RMJ - rock bolts with a metal joist; SSR - Split-Set rock bolts; $S W R$ - Swellex rock bolts; RPR - reinforced polymer rods

In accordance with the usual spraying method, the sprayer content is selected and adopted [25]. Let us calculate the amount of materials spent for the manufacture of shotcrete mixture in $1 \mathrm{~m}^{3}$. In our case, the composition of two-component spraying is taken, that is $\mathrm{C}: \mathrm{S}=1: 2$. Amount of materials consumed for $1 \mathrm{~m}^{3}$ of shotcrete mixture is presented in Table 3 .

Table 3. Amount of materials consumed for $1 \mathrm{~m}^{3}$ of shotcrete mixture with various compositions

\begin{tabular}{ccc}
\hline $\begin{array}{c}\text { Name of } \\
\text { materials }\end{array}$ & $\begin{array}{c}\text { Amount of materials in concrete mixes } \\
\text { with various composition }(\text { at } \mathrm{C}: \mathrm{S})\end{array}$ \\
\cline { 2 - 3 } & $\mathrm{C}: \mathrm{S}=1: 2$ & $\mathrm{C}: \mathrm{S}=1: 3$ \\
\hline Cement, $\mathrm{m}^{3} / \mathrm{kg}$ & $0.298 / 476.8$ & $0.229 / 366.4$ \\
\hline Sand, $\mathrm{m}^{3}$ & 0.596 & 0.6894 \\
\hline Water, $\mathrm{m}^{3}$ & 0.104 & 0.08 \\
\hline
\end{tabular}

\section{Results and discussion}

According to the experimental results, $1 \mathrm{~m}^{3}$ of shotcrete mixture is sufficient to fasten the mine working of $20 \mathrm{~m}^{2}$, but in the process of fastening, about $20 \%$ of the concrete mixture is consumed. Due to the use of a combined support (rock bolt + shotcrete) for fastening the mine workings at the 10th Anniversary of Kazakhstan's Independence mine of the Khromtau field, we determine the step of lagging behind the face of the rock-bolt and shotcrete supports [11].

Based on the recommendations of the SNiP II-94-80 normative documents, given the moderate rock mass stability and the presence of fractures, to ensure safe operation in the face, the step of lagging of rock-bolt support behind the face should be $2 \mathrm{~m}$, after one withdrawal of face and displacement of mine working $-4 \mathrm{~m}$. The step of lagging of shotcrete support of the face is permissible to be up to $4 \mathrm{~m}$, after displacement of mine working - up to $6 \mathrm{~m}$. The data of passport of fastening are given in Table 4 and Figure 4.

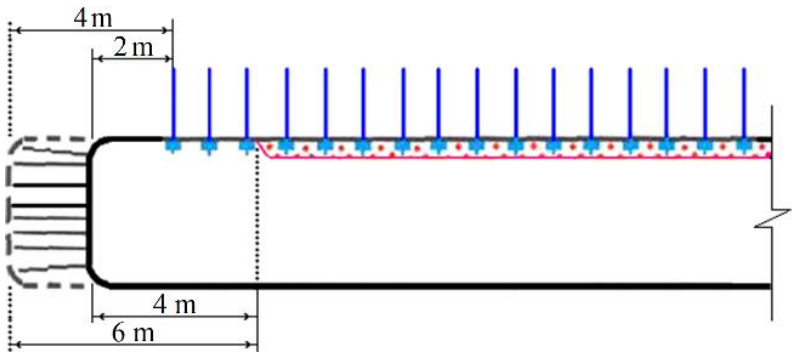

Figure 4. Scheme of lagging of combined support (rock-bolt and shotcrete) when driving the "Shtrek" mine working

The total length of the drift is $720 \mathrm{~m}$. Inner area of mine working $S_{i a}=5.70 \mathrm{~m}^{2}$, area during driving of mine working $S_{d a}=6.50 \mathrm{~m}^{2}$, inner width after fastening $B=2540 \mathrm{~mm}$, width of mine working $B_{1}=2640 \mathrm{~mm}$, height of mine working $H_{w}=2685 \mathrm{~mm}$.

The distance between rock bolts is taken equal to $0.7 \mathrm{~m}$. Based on this, we determine the number of rock bolts set along the entire length of mine working: $720 / 0.7 \mathrm{~m}=1028$ rows. Taking into account that in the cross section of mine working, 4 rock bolts in a row is set, for all the mine working of the site $(720 \mathrm{~m}) 1028 \times 4=4112$ rock bolts are used. The total amount of combined fastening materials (rock bolts + metal mesh + shotcrete) used along the entire mine working length $(720 \mathrm{~m})$ is determined in Table 4.

Table 4. Amount of materials for combined support (rock bolts + metal mesh + shotcrete) used in the mine working with length of $720 \mathrm{~m}$

\begin{tabular}{lc}
\hline \multicolumn{1}{c}{ Types and basic parameters of supports } & Parameters \\
\hline Area during driving of mine working, $\mathrm{m}^{2}$ & 6.5 \\
\hline Net area of extraction site, $\mathrm{m}^{2}$ & 5.7 \\
\hline Rock-bolt support & \\
\hline $\begin{array}{l}\text { The number of rock bolts set in one row } \\
\text { of the mine working cross section }\end{array}$ & 1028 \\
\hline $\begin{array}{l}\text { A row of rock bolts for setting along } \\
\text { the entire length of mine working }\end{array}$ & 4112 \\
\hline $\begin{array}{l}\text { The total number of rock bolts set along } \\
\text { the entire length of mine working of } 720 \mathrm{~m}\end{array}$ & 8.7 \\
\hline $\begin{array}{l}\text { The amount of concrete mixture injected } \\
\text { into the rock-bolt hole, } \mathrm{m}^{3}\end{array}$ & $70-90$ \\
\hline Load-bearing capacity, $\mathrm{kN}$ & 1220 \\
\hline Number of metal meshes, $\mathrm{m}^{2}$ & \\
\hline Shotcrete support & $\mathrm{C}: \mathrm{S}: \mathrm{W}=1: 2: 0.35$ \\
\hline Shotcrete composition & \\
\hline $\begin{array}{l}\text { Amount of components used in } 1 \mathrm{~m}^{3} \text { of } \\
\text { precast concrete mixture, }\left(\mathrm{m}^{3}\right):\end{array}$ & 0.298 \\
Cement & 0.596 \\
$\begin{array}{l}\text { Sand } \\
\text { Water }\end{array}$ & 0.104 \\
\hline $\begin{array}{l}\text { Individual amount of components for } \\
\text { shotcrete mixtures for the entire mine work- } \\
\text { ing of } 720 \mathrm{~m},\left(\mathrm{~m}^{3}\right) \text { : }\end{array}$ \\
$\begin{array}{l}\text { Cement } \\
\text { Sand } \\
\text { Water }\end{array}$ \\
\hline Total volume of shotcrete mixture, $\mathrm{m}^{3}$ & 393 \\
\hline
\end{tabular}

The cost for fastening materials when using a combined support for a drift mine working with a length of $720 \mathrm{~m}$ is calculated in Table 5.

Accordingly, the cost of only fastening materials when using a combined support in the mine working with a length of $720 \mathrm{~m}$ amounts to 6879690 tenge. 
Table 5. Cost of materials for combined supports in a drift mine working with a length of $720 \mathrm{~m}$

\begin{tabular}{lccc}
\hline \multicolumn{1}{c}{$\begin{array}{c}\text { Materials for a } \\
\text { combined support }\end{array}$} & $\begin{array}{c}\text { Price per } \\
\text { unit, } \$\end{array}$ & $\begin{array}{c}\text { The amount } \\
\text { used for the } \\
\text { entire mine } \\
\text { working }\end{array}$ & $\begin{array}{c}\text { Total } \\
\text { cost, } \$\end{array}$ \\
\hline $\begin{array}{l}\text { Total number } \\
\text { f rock bolts, pcs }\end{array}$ & 1.22 & 4112 & 5029.27 \\
\hline $\begin{array}{l}\text { The cost of the concrete } \\
\text { mixture injected into } \\
\text { the rock-bolt hole }\end{array}$ & 20 & 8.7 & 173.93 \\
\hline $\begin{array}{l}\text { The cost } \\
\text { of metal meshes }\end{array}$ & 2.82 & 1120 & 3161.17 \\
\hline Shotcrete mixture & 20 & 391 & 7817.07 \\
\hline Total & & & 16181.44 \\
\hline
\end{tabular}

A comparative analysis of the cost of materials when using metal-arch support and combined support is given in Figure 5.

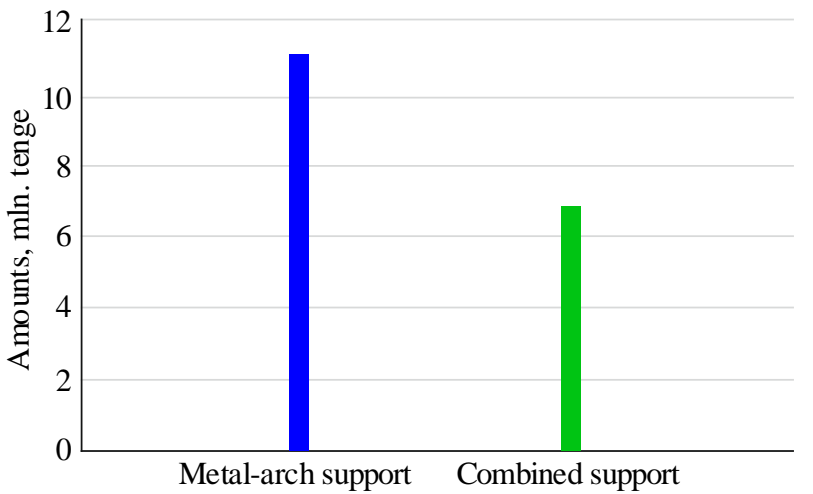

Figure 5. Comparative technical-and-economic indicators of the expenditures for materials used for metal-arch and combined supports

Based on the obtained weekly data, the general state of the mine workings (mining and drifting) is analysed, hazardous areas are identified and the operational life of mine working is predicted depending on the planned duration of mine working exploitation. In the case of reducing the operational life of mine working, corrective measures (repair and restoration work) are taken, depending on the planned duration of mining operations.

According to the weekly results obtained from the benchmark stations set on the block No. 1, hazardous areas have been identified along the ore drift No. 8/1. For 3 months, an acceleration of the benchmark station displacement has been observed in this area. The maximum displacement is $92 \mathrm{~mm}$ and the average velocity is $1.19 \mathrm{~mm} /$ day as of $09 / 02 / 2020$ and the mine working operational life is predicted for 1 month. Mining operations were planned for 3 months with a continuous front, because of which it was necessary to take measures for mining operations:

1. Option 1 provides not to change the front of mining operations, but to apply additional fastening along the ore drift No. 8/1 to ensure the operational life of mine working for 3 months.

2. Option 2 provides for a change in the front of mining operations from continuous to diagonal in advance of mining operations along the ore drift No. $8 / 1$ without additional fastening with an operational life of mine working for 1 month.
Based on the research results, the option No. 2 is recommended with a change in the front of mining operations from continuous to diagonal, without the expenditures for additional fastening. Ore drift No. 8/1 from the beginning (04/01/2020) to the end of mining operations (11/16/2020) has served for 7 months, ensuring the safe mining and without the expenditures for additional fastening. To date, there are no areas with large displacements.

Figure 6 shows the benchmarks, in which the support destruction occurs at the $+100 \mathrm{~m}$ sub-level and one benchmark at the $+60 \mathrm{~m}$ sub-level of the ore drift No. 8/1, mined out at the initial stage of destruction.

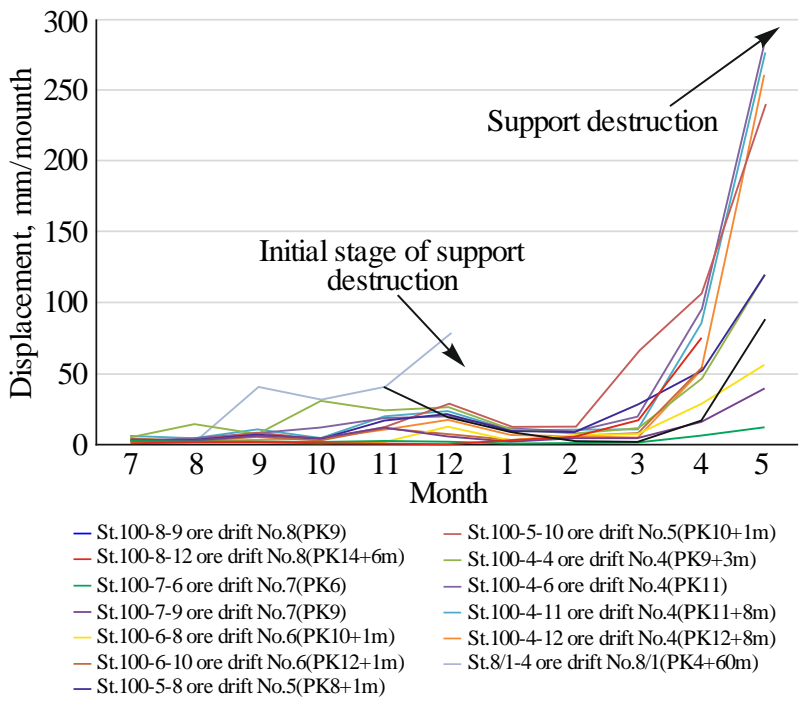

Figure 6. The benchmark station displacement at the $+100 \mathrm{~m}$ sublevel and a benchmark at the $+60 \mathrm{~m}$ sub-level

On average, the displacements from August to February have not exceeded $40 \mathrm{~mm} / \mathrm{month}$. Active displacements began in March and continued for 2 months until the destruction of support. Below, as an example, one of the many cross-sections of No. 8/1 mine working in the process of driving (black) and displacements over time (in red) is presented in Figure 7.

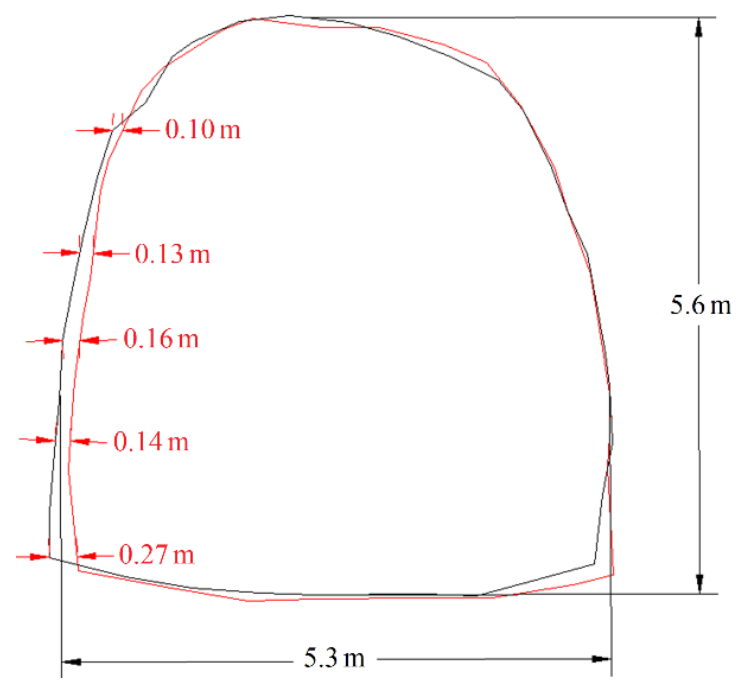

Figure 7. Displacement of the mine working walls of the ore drift No. $8 / 1$ at the $+60 \mathrm{~m}$ sub-level in the area of the cross section 32 
It is observed from this figure, that the main part of the displacements $(27 \mathrm{~mm})$ occur in the lower area of the mine working side, and the smallest one - in the upper area $(10 \mathrm{~mm})$ with a mine working width of $5.3 \mathrm{~m}$ and a height of $5.6 \mathrm{~m}$. Also, with these displacements, fractures and their opening appear. Figure 8 shows the stress curves in the mine working cross-section of the ore drift No. 8/1, at the $+60 \mathrm{~m}$ sub-level, block 1 along the cross-section 37 . The maximum value is $18 \mathrm{MPa}$ with a mine working width of $5.4 \mathrm{~m}$.

Figures 9-11 show the rock mass state and the redistribution of the load before, during and after driving. Figures 9-11 show the results of modelling the maximum stresses (S1) at different stages of mining operations. It can be seen from Figure 9 that the Sigma 1 value is $9.35 \mathrm{MPa}$ in the virgin mass.

During mining operations, that is, after driving two parallel mine workings $5.5 \mathrm{~m}$ wide, Sigma 1 value is distributed around these mine workings. The maximum stress concentration falls on the arched part of the mine working, fastened with the use of combined support, and its value is $18.0 \mathrm{MPa}$, as shown in Figure 10. Figure 11 shows the results of a numerical analysis by the finite element method after driving and fastening of all mine workings.

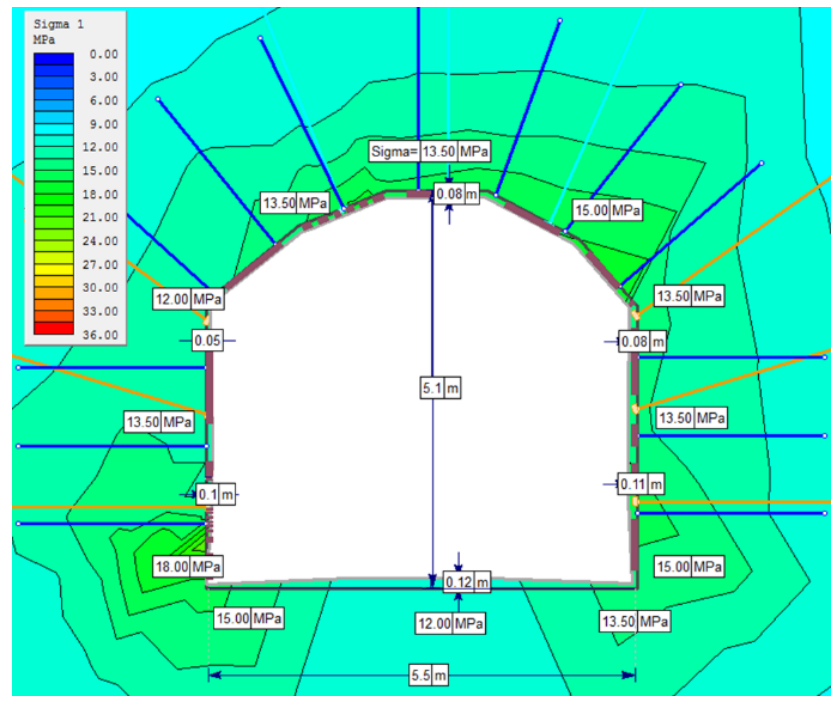

Figure 8. Curves of stresses in the mine working cross-section of the ore drift No. 8/1, at the $+60 \mathrm{~m}$ sub-level, block 1 along the cross-section 37

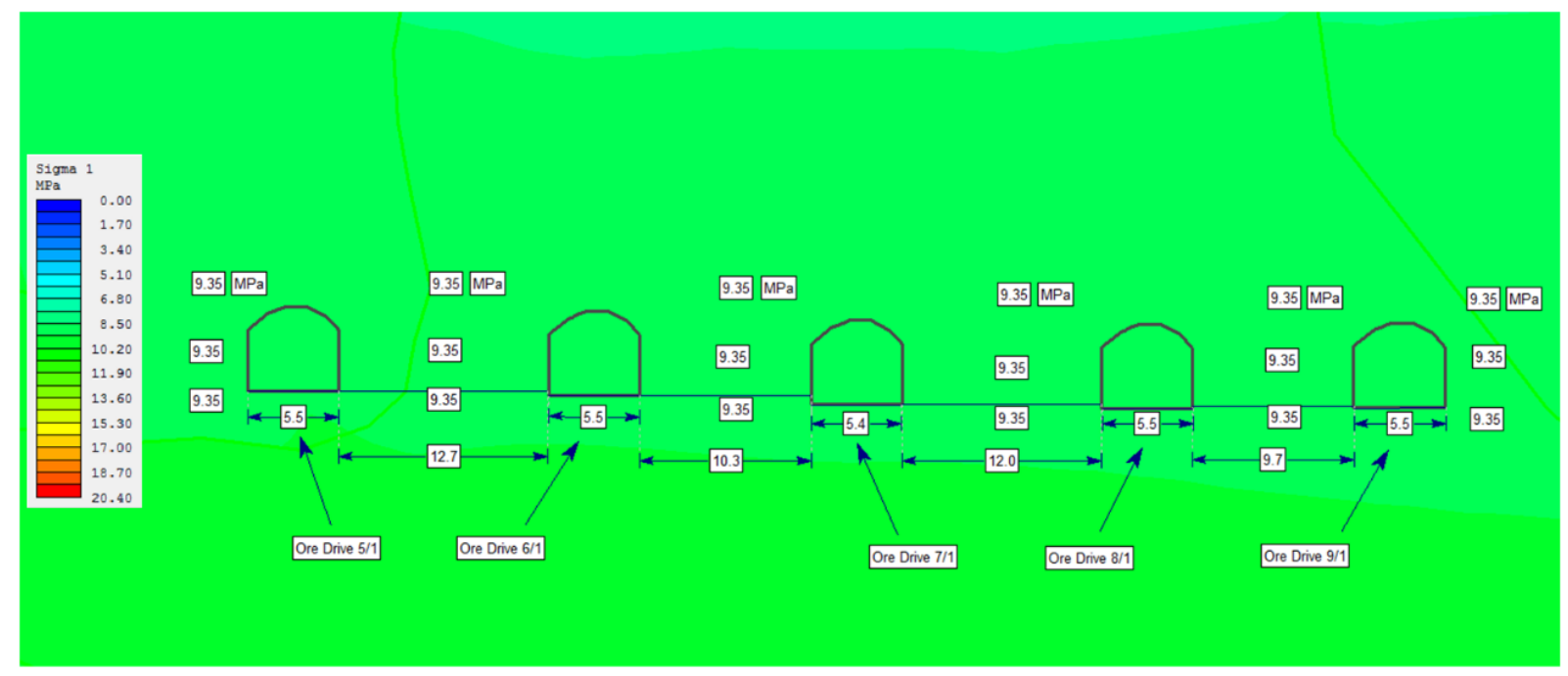

Figure 9. The rock mass state in the area of $+60 \mathrm{~m}$ sub-level, block 1 before driving of mine workings along the cross section 32

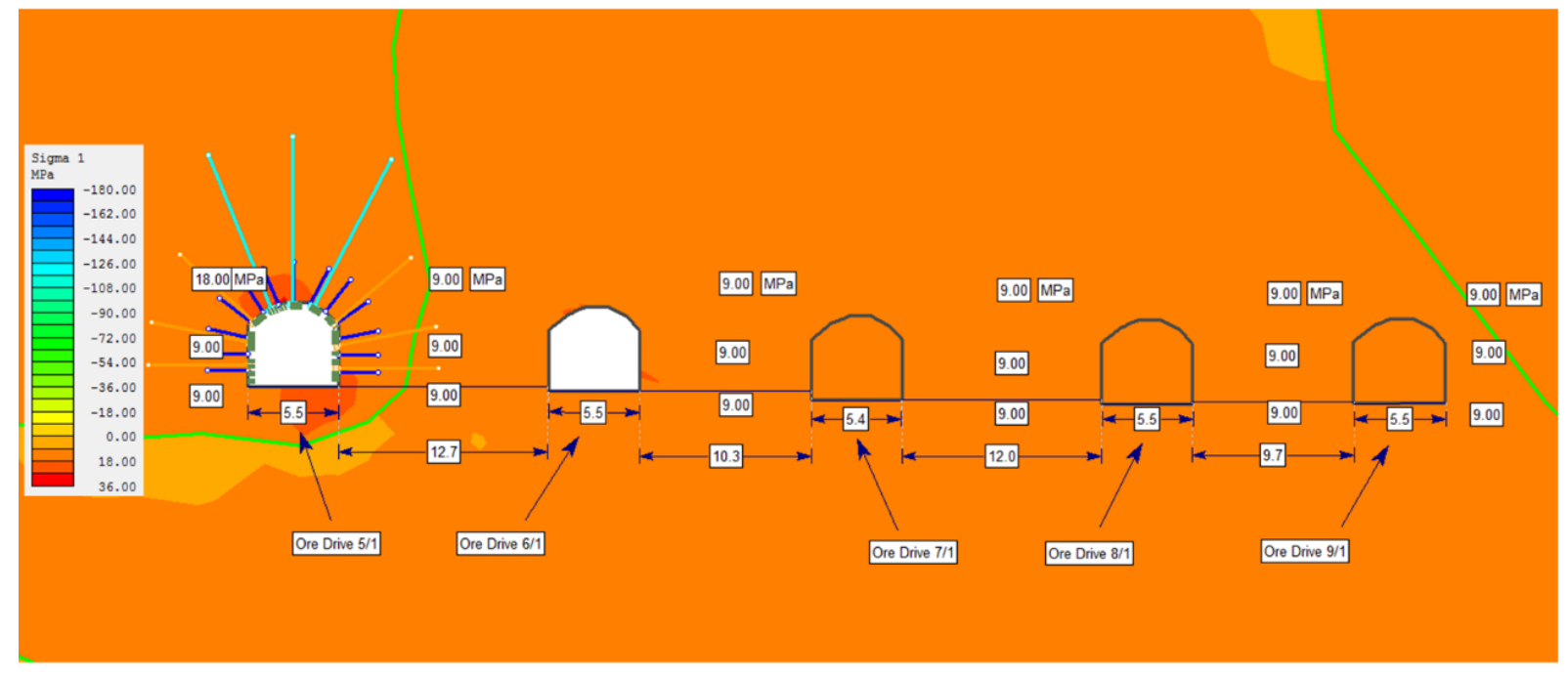

Figure 10. The rock mass state in the area of $+60 \mathrm{~m}$ sub-level, block 1 during driving of mine workings along the cross section 32 


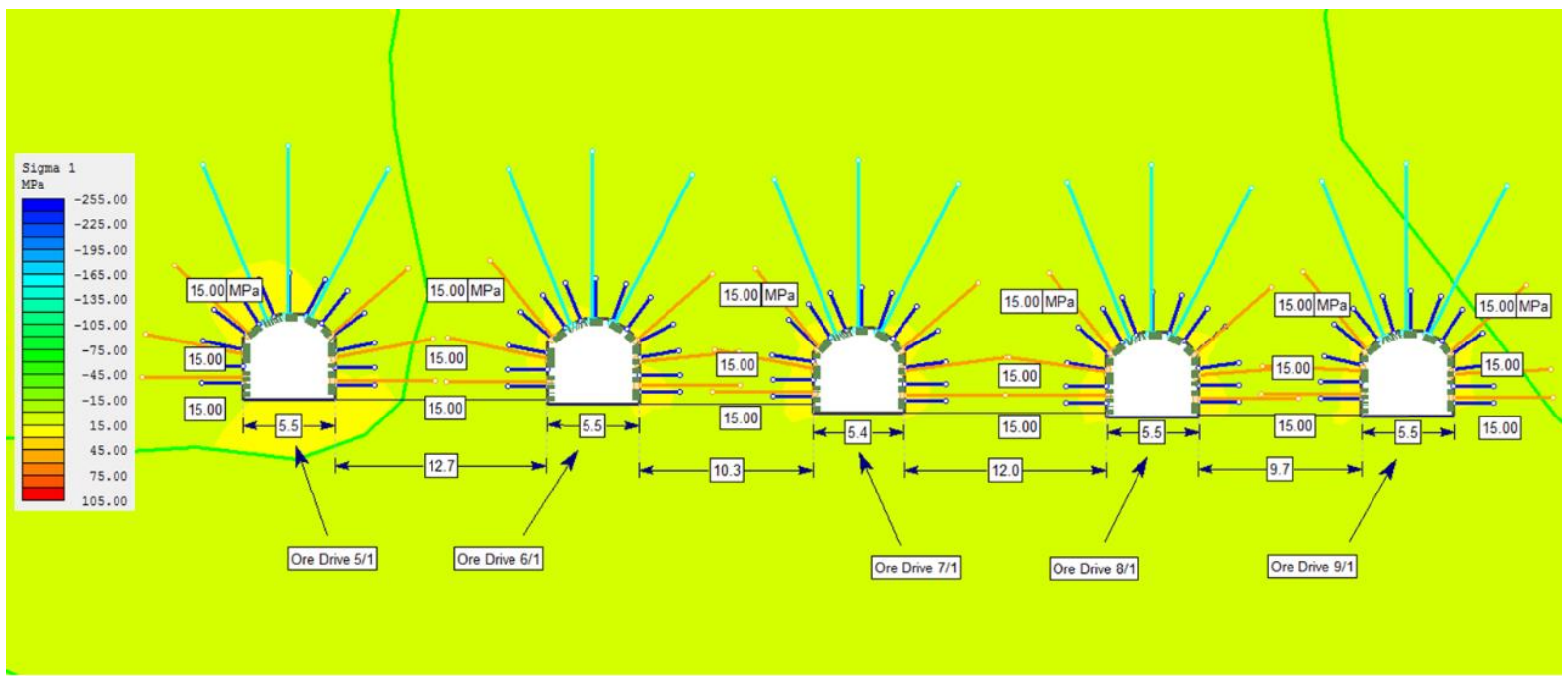

Figure 11. The rock mass state in the area of $+60 \mathrm{~m}$ sub-level, block 1 after driving of mine workings along the cross section 32

The modeling results presented in Figure 11, after laying of all mine workings and their fastening with combined support (rock bolts, cable and shotcrete), indicate that the stresses acting on the mine working are equally distributed across all mine workings, and the value of the maximum stresses decreases to $15.0 \mathrm{MPa}$, that is, the stresses acting on mine workings are the same from all sides Sigma $1=\operatorname{Sigma} 2=$ Sigma3 (hydrostatics).

\section{Conclusions}

The paper studies the technical and technological peculiarities of the improved combined support used for fastening in the conditions of rock mass stability. In particular, quality indicators, economic, scientific-theoretical and practical aspects of using this support have been compared with the metal support studied in the previous project. In addition, the effectiveness has been revealed of the combined support during the mining operations at the horizon of $-480,720 \mathrm{~m}$ long at the $10^{\text {th }}$ Anniversary of Kazakhstan's Independence mine at the Khromtau field.

The main results and conclusions of the paper are as follows:

1. The physical-mechanical properties and stability indicators of rocks along the strike of the mass, in which the "Shtrek" mine working will be conducted with a length of $720 \mathrm{~m}$ at the horizon of -480 at the $10^{\text {th }}$ Anniversary of Kazakhstan's Independence mine at the Khromtau field, have been studied. The expediency of using a combined support (together with rock bolts + metal meshes + shotcrete on top) at the research object has been substantiated.

2. Physical and mechanical properties of mine workings, stability parameters, stress-strain conditions have been calculated according to the SNiP II-94-80 method. The decisions on the possibility of using standard metal-arch support and combined support (rock bolt + shotcrete) have been studied and adopted, according to the SNiP II-94-80 method. The latter is an effective support that can constantly withstand mining operations until the specified operational life. Its design peculiarities have been studied, as well as analyses and examinations have been carried out on the effectiveness of using this support. During the research, the technologies for fastening the underground mine workings, including the peculiarities of the supports used in practice, have been thoroughly developed and analyzed. The factors influencing the structure, performance and efficiency of the support have been revealed, and also analytical analyses, mathematical, computer programmed methods of calculation have been applied with comparative expert studies.

3. The technological parameters, as well as technicaland-economic indicators of using the metal and combined supports (rock bolts + metal mesh + shotcrete), which are presented for fastening the mine working, have been studied. As a result of the research, it has been revealed that along the strike of the mine working, it is possible to use a combined support depending on the parameters of the rock mass stability.

4. The technical-and-economic indicators of material expenditures for metal and combined support (rock bolts + metal mesh + shotcrete), presented for fastening the mine working, have been comparatively studied and calculated. If to analyze the comparative studies from an economic point of view, in the case of using a metal-arch support in the mine working with a length of $720 \mathrm{~m}$, the cost of fastening amounts to 11560000 tenge. During the research, it has been revealed that the cost of materials consumed for a combined support, under equal conditions from all sides, amounts to 6879690 tenge. When comparing the economic results, it has been determined that when using a combined support for fastening the mine working, the cost of materials is reduced by 1.7 times. That is, the research results indicate that when using the method of fastening with an improved combined support in the mine working with a length of $720 \mathrm{~m}$, it is possible to save 4680310 tenge.

5 . In the course of research, it has been determined that the velocity of driving of the mine working when using the proposed improved combined support is higher by 1.6 times than when using the metal support.

\section{Acknowledgements}

We would like to express our gratitude to all the editorial staff and reviewers for the quality work on our material. We are pleasantly surprised by the prompt and well-organized feedback from the editors. Of special note is the wellorganized and well-coordinated team work. We would like to express our gratitude to Arystan Ibatolla Daiyrovich, our Academic Advisor, for valuable advice when planning the research and recommendations on the design of this paper. 


\section{References}

[1] Kuznetsov, Y.N., \& Chernyshov, A.V. (2019). To the issue of ensuring opening strength of the underground mine workings. Occupational Safety in Industry, (1), 19-25. https://doi.org/10.24000/0409-29612019-1-19-25

[2] Pivniak, H.H., Pilov, P.I., Pashkevych, M.S., \& Shashenko, D.O. (2012). Synchro-mining: Civilized solution of problems of mining regions' sustainable operation. Naukovyi Visnyk Natsionalnoho Hirnychoho Universytetu, (3), 131-138.

[3] Arystan, I.D., Abeuov, E.A., \& Abdrashev, R.M. (2019). Kreplenie gorizontal'nykh gornykh vyrabotok $\mathrm{v}$ usloviyakh shakht Donskogo GOKa. Sovremennye Tendentsii i Innovatsii v Nauke i Proizvodstve, 126.1-126.2.

[4] Rudakov, D., \& Sobolev, V. (2019). A mathematical model of gas flow during coal outburst initiation. International Journal of Mining Science and Technology, 29(5), 791-796. https://doi.org/10.1016/j.ijmst.2019.02.002

[5] Omarova, G., Baibatsha, A., \& Abdykirova, G.Z. (2019). Flotation enrichment of enrichment factory tailings for use as technogenic ore. International Multidisciplinary Scientific GeoConference Surveying Geology and Mining Ecology Management, 19(1), 195-202. https://doi.org/10.5593/sgem2019/1.1/s01.024

[6] Sobolevskyi, R., Korobiichuk, V., Iskov, S., Pavliuk, I., \& Kryvoruchko, A. (2016). Exploring the efficiency of applying fractal analysis for the process of decorative stone quality control. EasternEuropean Journal of Enterprise Technologies, 6(3(84)), 32-40. https://doi.org/10.15587/1729-4061.2016.85227

[7] Arystan, I.D., Baizbaev, M.B., Mataev, A.K., Abdieva, L.M., \& Bogzhanova, Z.K. (2020). Selection and justification of technology for fixing preparatory workings in unstable massifs on the example of the mine "10 Years of Independence of Kazakhstan". Ugol, (6), 10-14. https://doi.org/10.18796/0041-5790-2020-6-10-14

[8] Matayev, A.K., Musin, A., Abdrashev, R.M., Kuantay, A.S., \& Kuandykova, A.N. (2021). Substantiating the optimal type of mine working fastening based on mathematical modeling of the stress condition of underground structures. Naukovyi Visnyk Natsionalnoho Hirnychoho Universytetu, (3), 57-63. https://doi.org/10.33271/nvngu/2021-3/057

[9] Hoek, E., Carranza-Torres, C., \& Corkum, B. (2002). Hoek-Brown failure criterion-2002 edition. Proceedings of NARMS-Tac, 1(1), 267-273.

[10] Duncan, J.M. (1996). State of the art: limit equilibrium and finite-element analysis of slopes. Journal of Geotechnical Engineering, 122(7), 577596. https://doi.org/10.1061/(ASCE)0733-9410(1996)122:7(577)

[11] Imashev, A.Zh., Bakhtybaev, N.B., Tileukhan, N., Zhunusbekova, G., \& Zhakanov, K.K. (2013). Chislennoe modelirovanie geomekhanicheskikh protsessov s pomoshch'yu programmy "Faza 2". Gornyy Zhurnal Kazakhstana, (7), 10-13

[12] Khalymendyk, I., \& Baryshnikov, A. (2018). The mechanism of roadway deformation in conditions of laminated rocks. Journal of Sustainable Mining, 17(2), 41-47. https://doi.org/10.1016/j.jsm.2018.03.004

[13] Nurpeissova, M., Bekbassarov, S., Bek, A., Kyrgizbaeva, G., Turisbekov, S., \& Ormanbekova, A. (2020). The geodetic monitoring of the engineering structures stability conditions. Journal of Engineering and Applied Sciences, 12(11), 9151-9163. https://doi.org/10.3923/jeasci.2017.9151.9163

[14] Imashev, A., Suimbaeva, A., Zholmagambetov, N., Takhanov, D., \& Abdimutalip, N. (2018). Issledovanie vozmozhnykh zon neuprugogo deformirovaniya massiva gornykh porod. Izvestiya Natsional'noy Akademii Nauk Respubliki Kazakhstan, Seriya GeologoTekhnicheskikh Nauk, 2(428), 177-184.

[15] Kieush, L., Boyko, M., Koveria, A., Yaholnyk, M., \& Poliakova, N. (2020). Manganese Sinter Production with Wood Biomass Application. Key Engineering Materials, 844, 124-134. https://doi.org/10.4028/www.scientific.net/kem.844.124

[16] Begalinov, A., Shautenov, M., Almenov, T., Bektur, B., \& Zhanakova, R. (2019). Prospects for the effective use of reagents based on sulfur compounds in the technology of extracting gold from resistant types of gold ore. Journal of Advanced Research in Dynamical and Control Systems, 11(8), 1791-1796.

[17] Shustov, O., Pavlychenko, A., Bondarenko, A., Bielov, O., Borysovska, O., \& Abdiev, A. (2021). Substantiation into Parameters of Carbon Fuel Production Technology from Brown Coal. Materials Science Forum, (1045), 90-101. https://doi.org/10.4028/www.scientific.net/MSF.1045.90

[18] Sobolevskyi, R., Korobiichuk, V., Levytskyi, V., Pidvysotskyi, V., Kamskykh, O., \& Kovalevych, L. (2020). Optimization of the process of efficiency management of the primary kaolin excavation on the curved face of the conditioned area. Rudarsko-Geološko-Naftni Zbornik, 35(1), 123-137. https://doi.org/10.17794/rgn.2020.1.10

[19] Nurpeisova, M.B., Sarybaiev, O.A., \& Kurmanbaiev, O.S. (2016). Study of regularity of geomechanical processes development while developing deposits by the combined way. Naukovyi Visnyk Natsionalnoho Hirnychoho Universytetu, (4), 30-36.

[20] Sdvizhkova, Ye.A., Babets, D.V., \& Smirnov, A.V. (2014). Support loading of assembly chamber in terms of Western Donbas plough longwall. Naukovyi Visnyk Natsionalnoho Hirnychoho Universytetu, (5), 26-32.

[21] Shashenko, A., Gapieiev, S., \& Solodyankin, A. (2009). Numerical simulation of the elastic-plastic state of rock mass around horizontal workings. Archives of Mining Sciences, 54(2), 341-348.

[22] Babets, D.V., Sdvyzhkova, O.O., Larionov, M.H., \& Tereshchuk, R.M (2017). Estimation of rock mass stability based on probability approach and rating systems. Naukovyi Visnyk Natsionalnoho Hirnychoho Universytetu, (2), 58-64.

[23] Sotskov, V., \& Saleev, I. (2013). Investigation of the rock massif stress strain state in conditions of the drainage drift overworking. Annual Scientific-Technical Collection - Mining of Mineral Deposits, 197-201. https://doi.org/10.1201/b16354-35

[24] Zeynullin, A.A., Abeuov, E.A., Demin, V.F., Aliev, S.B., Kaynazarova, A.S., \& Kaynazarov, A.S. (2021). Estimation of ways to maintain mining works based on the application of anchor anchoring in the mines of the Karaganda coal basin. Ugol', (2), 4-9. https://doi.org/10.18796/0041-5790-2021-2-4-9

[25] Arystan, I.D., Baizbaev, M.B., \& Abdrashev. R.M. (2019). Tekhnologii provedeniya $i$ krepleniya gornykh vyrabotok. Aktobe, Kazakhstan: ARGU im. K. Zhubanova, 99 p.

\section{Дослідження технології кріплення гірничих виробок в умовах нестійких масивів}

\section{А. Матаєв, А. Абдієв, А. Кидрашов, А. Мусін, Н. Хватіна, Д. Кауметова}

Мета. Визначення стійкості гірських порід за простяганням масиву, в якому буде проводитися штрекова виробка горизонту -480 м 3 розглядом можливості застосування поліпшених типів кріплень в умовах шахти “10 років Незалежності Казахстану” Хромтауського родовища, з обгрунтуванням застосування ефективного типу кріплення, що підвищує техніко-технологічні, експлуатаційні та економічні показники шахти.

Методика. Чисельне моделювання напружено-деформованого стану масиву гірських порід в умовах шахти було виконано у програмі RS2 у двомірній постановці. Стан породного масиву та фізіко-механічні властивості гірських порід визначаються згідно СНіП-у ІІ-94-80 залежно від категорії стійкості порід.

Результати. Встановлено, що найбільш раціональним типом кріплення у досліджуваному руднику є комбіновані кріплення 3 анкерів і набризгбетона. Визначено ефективність і перспективи застосування комбінованих кріплень, що забезпечує зниження їх матеріаломісткості та вартості, що підвищує надійність виробок та продуктивність праці прохідників. Застосування комбінованих кріплень дозволяє збільшити економію матеріалів кріплення в 1,7 рази, а також збільшити швидкість проходки в 1,6 рази у порівнянні з металевим кріпленням.

Наукова новизна. У статті запропоновано новий підхід до обгрунтування ефективного методу кріплення шляхом зіставлення витрат при проходці горизонтальних підземних гірничих виробок в гірничо-геологічних умовах шахти “10 років Незалежності Казахстану".

Практична значимість. Результати дослідження можу бути використані при плануванні гірничих робіт, зокрема стійких способів кріплення, на шахті “10 років Незалежності Казахстану” Хромтауського родовища, а також на інших гірничих підприємствах 3 подібними гірничо-геологічними умовами.

Ключові слова: шахта, руда, анкер, порода, металеве кріплення, штрек, родовище 


\section{Исследование технологии крепления горных выработок в условиях неустойчивых массивов}

\section{А. Матаев, А. Абдиев, А. Кыдрашов, А. Мусин, Н. Хватина, Д. Кауметова}

Цель. Определение устойчивости горных пород по простиранию массива, в котором будет проводиться штрековая выработка горизонта -480 м с рассмотрением возможности применения улучшенных типов крепей в условиях шахты “10 лет Независимости Казахстана" Хромтауского месторождения, с обоснованием применения эффективного типа крепления, повышающего техникотехнологические, эксплуатационные и экономические показатели шахты.

Методика. Численное моделирование напряженно-деформированного состояния массива горных пород в условиях шахты было выполнено в программе RS2 в двухмерной постановке. Состояние породного массива и физико-механические свойства горных пород определялись по СНиП-у II-94-80 в зависимости от категорий устойчивости пород.

Результаты. Установлено, что наиболее рациональным типом крепления в иследуемом руднике являются комбинированные крепи из анкеров и набрызгбетона. Определены эффективность и перспективы применения комбинированных крепей, обеспечивающих снижение их материалоемкости и стоимости, повышающие надежность выработок и производительность труда проходчиков. Применение комбинированной крепи позволяет увеличить экономию материалов крепи в 1,7 раза, а также увеличить скорость проходки в 1,6 раза по сравнению с металлической крепью.

Научная новизна. В статье предложен новый подход к обоснованию эффективного метода крепления путем сопоставления затрат при проходке горизонтальных подземных горных выработок в горно-геологических условиях шахты "10 лет Независимости Казахстана”.

Практическая значимость. Результаты исследования могу быть использованы при планировании горных работ, в частности устойчивых способов крепления, на шахте “10 лет Независимости Казахстана” Хромтауского месторождения, а также других горных предприятиях с подобными горно-геологическими условиями.

Ключевые слова: шахта, руда, анкер, порода, металлическая крепь, штрек, месторождение 